\title{
The Impact of Authentic Material Use on Development of the Reading Comprehension, Writing Skills and Motivation in Language Course ${ }^{1}$
}

\section{Ş. Dilek Belet Boyacı}

Assoc. Prof., Anadolu University, Turkey, sdbelet@anadolu.edu.tr

Mediha Güner

Anadolu University, Turkey, medihaguner@anadolu.edu.tr

The objective of the present study was to determine the impact of authentic taskbased authentic material on reading comprehension, writing skills and writing motivation in the Turkish language course. The study was conducted with mixed design methodology. Quantitative data were collected with the quasi-experimental with pre-test post-test with control group design in the study. Qualitative data were collected with a semi-structured interview form. The study was conducted in a primary school located in Eskişehir urban center during the 2014-2015 academic year spring semester. The experiment group included 22 students and the control group included 24 students. The data were collected with Reading Comprehension Test (Bulut, 2013), Writing Motivation Scale (Öztürk, 2013), Writing Skills Scale (Uysal, 2009), and a semi-structured interview form. Analysis of the quantitative data was conducted with independent samples t-test and qualitative data were analyzed with descriptive analysis. Study findings demonstrated that use of authentic task-based authentic material in the Turkish language course improved the reading comprehension, writing skills and writing motivation of 4th grade primary school students. Furthermore, it was found that students who participated in the study had positive views on the Turkish language course instructed with authentic task-based authentic material.

Keywords: primary school, authentic task, authentic material, reading comprehension, writing skills, writing motivation

\footnotetext{
${ }^{1}$ This paper is based on a thesis study titled "The Effects of Authentic Task-Based Authentic Material Usage on Students' Reading Comprehension, Writing Skills and Writing Motivation". This thesis study was supported by Anadolu University. Project Number: 1503E128

Citation: Belet Boyac1, S. D., \& Güner, M. (2018). The Impact of Authentic Material Use on Development of the Reading Comprehension, Writing Skills and Motivation in Language Course. International Journal of Instruction, 11(2), 351-368. https://doi.org/10.12973/iji.2018.11224a
} 


\section{INTRODUCTION}

It is clear that the most significant component of the 21 st century educational approach is the synergy between the real world and the school environment (Bektaş \& Horzum, 2012, p. 9). This component is essential due to the significance of knowledge, skills, attitudes and behavior acquired by the students at school level in the real world. One of the skills that are acquired at school is literacy skills which are intertwined with daily life. Reading is the most basic skill that an individual can utilize in every realm of his or her life. An individual is expected to read any material she or he encounters in daily life, not only those assigned in school. In the process of making sense of each written material in everyday life, reading skill is the most required skill of all. Furthermore, the writing skill is a skill that we need in every aspect of life in expressing our wishes, our desires, our thoughts, in providing information to others, celebrations, keeping a record of our memories and knowledge. Despite the importance of literacy in daily and academic life, it is a fact that students experience reading and writing problems in Turkey. The high number of students who received zero or very low scores in exams taken during graduation from the elementary, junior high and high schools according to the data provided by 2001 PIRLS (Progress in International Reading Literacy Study) and 2003, 2009, 2012 and 2015 PISA (Program for International Student Assessment) surveys and the high number of college graduates without reading comprehension skills demonstrate the problems in development of required skills, especially the reading comprehension skill, in native language and reading education in Turkey. The students in Turkey experience reading comprehension problems and the activities and studies related to the acquisition of reading skills are inadequate in Turkey. Besides the reading skills, previous studies demonstrated that there are problems in the development of written expression skills as well (Alkan, 2007; Volman, van Schendel and Jongmans, 2006). Despite the problems in the development of writing skills and the inability of students to achieve the desired written expression skill levels, these problems are not adequately addressed in schools due to the difficulty of the development of these skills. Furthermore, this also leads to the low writing motivation among the students as well.

According to Caseley (2004, p. 5), there is a contradiction and inconsistency between the training at school and the experiences of the students in daily life. Due to this factor, students cannot observe real life relationships in the learning process at school. However, while literacy skills are so intertwined with life, it is not possible to conceive the fact that the methods of developing these skills could be disconnected from real life. Furthermore, the technological advances that are experienced in Turkey and in the world in the field of communications require the orientation of literacy skills education towards communication. In short, plans and programs that would be conducted for the development of literacy skills should be functional and aim the field of communications. The objective of the development of literacy skills should be to enable the individual to communicate with others and to benefit from these skills in all areas of daily life. Thus, using daily life materials, organizing activities and utilizing various tasks that can take place in the everyday life of the students would improve students' literacy skills and increase their motivation to use language skills. One of the approaches that aim to transfer daily life conditions to the classroom environment and to connect the students 
with everyday life practices is the authentic learning approach. Authentic learning approach allows students to transfer the knowledge and skills they acquire at school to everyday life, thus rendering learning more meaningful.

Tackling with authentic and realistic activities that encourage students to collaborate in a complex structure shows that learning takes place in an authentic manner (Herrington, Reeves \& Oliver, 2010). Authentic learning is based on authentic tasks and material. Authentic tasks are student-centered, interactive, intriguing, and daily life-based tasks. These tasks are also conducted using authentic material that possesses the same features. According to Cholewinski (2009, p. 286), the concept of authenticity is synonymous to real-life objects used to teach real life situations in a classroom environment. This concept focuses on the use of material that was not developed specifically for teaching purposes. Bacon and Finemann (1990, p. 502) defined authentic material as material produced by the individual, whose native language is the language instructed in the course, without any educational purposes. According to Lee (1995, p. 324), these materials are generally considered more interesting by the students since they were not produced for educational purposes and related to daily problems and activities. Considering the most general objective of language teaching process is to develop verbal and written communication skills, exposure of the students to the maximum volume of verbal and written material, deliberate use of daily material in the classroom to develop their skills is important in motivating the students and improving their ability to use the material they encounter in daily life to develop their skills consciously. Authentic materials provide students a natural language that helps them improve their communication skills. Through these materials, the natural use of the language is introduced to the students, and they are positively motivated about the language and the culture. These materials also contain cultural traits based on the intended use and the context in which they are used. The fact that the material contains the actual uses of the language allows the related culture to be reflected directly in the language. Furthermore, introducing daily material to the classroom environment attracts the interest of students.

As the students encounter the examples and material introduced in the classroom in daily life, instruction expands beyond the realm of the classroom. The students, who encounter the topics, examples and materials discussed in the class outside the classroom, would establish a connection between the course and their lives (Doğan, 2014). It should not be forgotten that such examples would contribute to the improvement of positive attitudes and motivation of the students in conveying the course knowledge to the daily life. Gebhard (1996, cited by Oura, 2001, p. 68) grouped authentic materials under three categories. Authentic audio/visual materials include TV commercials, quiz shows, video clips, cartoons, movies, soap operas, radio dramas and radio commercials. Authentic visual materials include slides, pictures, photographs, children's drawings, non-verbal street signs, skylines, magazine pictures, postcards, nonverbal picture books, and stamps. Authentic written materials are newspaper articles, movie commercials, astrology columns, sports news reports, obituaries, recommendation columns, lyrics, restaurant menus, street signs. According to Lee (1995, p. 325), the most important criteria in selection of authentic material are textual authenticity, adequacy of content, its suitability for the objectives of the course and availability. 
However, when selecting the authentic material for use in the classroom, there are further issues that the teachers should consider. The most important of these issues is the requirement that the material should be used in a way that is similar to its use in the real world. This can also be called "real world purpose". For example, students should read a recipe not only to learn the words in that recipe or to improve their reading speed, but also to learn how to prepare the dish. Courses that are instructed using these materials should not focus on the instructional objective, but the instructional objective should be a part of the effort of the teacher to achieve the main objective by utilizing the material as it is used in a real-life situation. In other words, for the materials that are brought to the classroom environment to be considered authentic, teachers should organize authentic tasks for the use of these materials (Jacobson, Degener \& Purcell-Gates, 2003).

Thus, the use of authentic learning in Turkish language courses would maximize the integration between the real world and the school environment via authentic tasks based on real world experiences and authentic material used in the real world and would allow the individuals to transfer literacy skills to every area of daily life. In fact, it was emphasized in the principles of Turkish language education that real-life events experienced by children should be included in the curriculum, the experiences of the child outside the school should be considered as an educational environment, and the courses instructed in this environment and related instruction process should take place in a natural environment (Demirel \& Şahinel, 2006, p. 19). Furthermore, it is known that the daily life, past experiences of the child and all events that the child may encounter in daily life should be considered for the native language instruction to succeed. School prepares the students for life, in fact, school is life itself. Therefore, the topics in Turkish language courses can be constructed with the inspiration of every environment or material where the language is used.

Thus, the present study aimed to determine the effect of the use of authentic task based authentic material in Turkish language courses on students' reading comprehension, writing motivation and writing skills. Furthermore, the study aimed to examine the views of students on the use of authentic task based authentic materials in Turkish language courses. Based on the said objectives, the following sub-objectives were established:

1. Is there a statistically significant difference between the reading comprehension skills, writing skills and writing motivation of the study group, where authentic task based authentic materials were used in Turkish language course instruction, and the achievement of the students in the control group, where the authentic task based authentic materials were not used?

2. What are the views of students on the use of authentic task based authentic materials in Turkish language courses?

\section{METHOD}

\section{Research Design}

In the present study, a mixed design that included both quantitative and qualitative methods was adopted (Creswell, 2013, p. 217). The present study was conducted with 
explanatory mixed design. Study data were collected with conventional qualitative and quantitative designs; the study conducted with qualitative interviews was included in the empirical study. Qualitative interviews were conducted to support the empirical design. In other words, the present study necessitated both quantitative and qualitative data to address students' reading comprehension, writing skills and writing motivations, thus explanatory mixed design was utilized.

\section{Study Group}

Study participants included 4th grade students, who attended a primary school in Eskişehir urban center during the 2014-2015 academic year spring semester. The participants were selected with the criterion sampling technique due to the difficulty level of the material and the complexity of the tasks that needed to be performed. Furthermore, the criteria such as age, socioeconomic level, and volunteering to participate in the study were also considered. The study group included 22, the control group included 24 students.

\section{Data Collection Instruments}

Data collection instruments were used to collect different types of data based on the research questions and study methodology.

\section{Reading comprehension test}

The reading comprehension test, developed by Bulut (2013), was used in the study with the approval of the author. The reading comprehension test was designed based on 18 achievements such as "the student can distinguish the real elements from the imaginary ones in the manuscript she or he reads" and "the student can recognize the missing and unrelated information while reading." During the development of the test, Bulut (2013) initially designed a 54-item draft form. Following the pilot scheme, the item and test analyses were conducted. As a result of these analyzes, a total of 14 items were excluded from the test. Thus, the final Reading Comprehension Test included 40 items. Reading comprehension test included paragraph semantics, sentence semantics and word semantics fields. The average difficulty of the scores that could be obtained in the test is .65. This value indicates that the difficulty level of the test is moderate. Bulut (2013) calculated the KR-20 reliability as .90 , the same figure was calculated as .84 in the present study. These figures demonstrated that the achievement tests can be used within the context of the present study.

\section{Writing skills scale}

The writing skills scale, which was developed by Uysal (2009), was used in the study with the approval of the author. The scale included content, narration, organization, word selection and punctuation and grammar sub-categories. The scale criteria are evaluated by assigning $0,1,2,3$, and 4 points to the responses. The test was implemented both as the pre-test and post-test. The results of the pre-test that was conducted with 341 students were analyzed to determine scale reliability. Statistical analyzes demonstrated that the overall correlation coefficient for the scale was 0.94 . In the present study, the writing skills scale was scored by three field experts, one of whom 
was the author. 'Kendall Coefficient of Concordance' is used to determine inter-rater reliability in ordinal scales. Kendall W reflects a value between 0 (disagreement) and 1 (agreement) (Kendall \& Babington Smith, 1939). Based on the calculated Kendall W concordance coefficients, the coefficients of agreement between the field experts varied between .86 and .99 . These statistics demonstrated a high level of agreement between the raters.

\section{Writing motivation scale}

The Writing Motivation Scale, developed by Öztürk (2013), was used in the study to determine the writing motivation of the students with the approval of the author. The original overall scale Cronbach coefficient is .81. In the present study, the scale Cronbach alpha reliability coefficient was calculated as .93 . This scale is a 5-point Likert type scale including 5 factors. The factor loads of the scale that included 22 items vary between 0.42 and 0.75 . The 5 scale factors explain $54.27 \%$ of the total variance.

\section{Semi-structured interview form}

A semi-structured interview form was designed to determine the views of the students on the instruction of the curriculum using authentic task-based authentic material in the Turkish language course. When designing the interview form, the principles of ease of comprehension, focused questions, avoidance of multidimensional questions, using open-ended questions, avoidance of leading questions, designing alternative questions and probes, providing different types of questions and logical arrangement of questions were taken into consideration (Yıldırım \& Şimşek, 2013 , p. 54). The interview form was applied to two students as a pilot scheme after the expert opinion was obtained and student responses were analyzed and the questions that the students were unable to comprehend were restructured. Finally, the interview form was applied to all students in the class, except the abovementioned two students.

\section{Lesson plans and learning material}

When designing the lesson plans and learning material in the study, initially the literacy learning outcomes in "Innovations and Developments" and "Earth and Space" themes were identified. Then, based on the outcomes and authentic task based authentic material, lesson plans were developed for the relevant themes. The activities that were included in the plans completely utilized authentic tasks and material. The plan, developed based on the level of students, included tasks that the students could participate actively in the process and included authentic material such as children's literature works, newspapers, popular science books, children's magazines, scientific books for children, letters, cartoons, posters, brochures, handouts, invitations, commercials, movies, and internet sites. After the feedback was obtained from the field experts, the final plan was reviewed by the classroom teacher before implementation.

\section{Empirical process}

Before the tests were conducted, the author observed the class for three weeks to ensure orientation. The research was conducted by the author and the necessary information 
was provided to the classroom teacher about the instruction of the Turkish language course within the context of the study. The empirical procedures were initiated, and the reading comprehension test and the writing motivation scale pre-tests were applied to the students and the students were asked to write an essay to determine their writing skills. The empirical process lasted for a total of 10 weeks and 60 class periods. The activities were organized with real-life material and based on the real-life literacy objectives of the students, in other words, the courses were instructed with authentic task based authentic materials. All activities conducted by the students were carried out with real life material, and every text that was read or written served a real objective. All texts that were read were selected from various journals and newspapers, every material watched and listened was selected from authentic material such as television and radio broadcasts. The students authored texts to inform others, read and wrote the game rules before playing a game, read recipes to cook a meal, wrote letters to communicate and share their emotions and ideas with each other, read and wrote to construct menus, newspapers and blogs in the class.

\section{Data Analysis}

In the analysis of the study data, the skewness and kurtosis values were examined to determine whether the collected data exhibited normal distribution and it was observed that these values were within \pm 1 limits for the data collected with all data collection instruments. It was, thus, concluded that the data exhibited normal distribution and parametric tests were used (Tabachnick \& Fidell, 2000; Büyüköztürk, 2010). Hence, independent samples t-test (Büyüköztürk, 2010, p.39) was used. Qualitative data on the instruction of the course (student views) were collected with semi-structured interviews. Descriptive analysis was used in the analysis of the obtained data. In descriptive analysis, which aims to organize, interpret and present the collected data, first the data are described, then these descriptions are explained (Yıldırım \& Şimşek, 2011, p. 65).

\section{Study Validity and Reliability}

In mixed methodology, validity needs to be assessed for both qualitative and quantitative approaches (Creswell \& Plano Clark, 2014, p.221). The present study was designed with mixed methodology, and thus, the validity and reliability studies were conducted based on the utilized data collection instruments. While the reliability of the reading comprehension test and writing motivation scale used in the quantitative dimension of the study were determined by Cronbach alpha coefficient, the writing skills scale were scored by three experts, one of whom was the author and 'Kendall Coefficient of Concordance' that aims to determine inter-rater reliability in ordinal scales was calculated. Kendall W reflects a value between 0 (disagreement) and 1 (agreement) (Kendall \& Babington Smith, 1939). Based on the calculated Kendall W concordance coefficients, the coefficients of agreement between the field experts varied between .86 and .99 . These statistics demonstrated a high level of agreement between the raters. Credibility instead of internal validity, transferability instead of external validity, consistency instead of internal reliability, and confirmability instead of external reliability were utilized for the data collected with qualitative data collection instruments in the study (Lincoln \& Guba, 1985). 


\section{FINDINGS}

\section{Findings Obtained with Quantitative Data}

The reading comprehension test was applied to the students before and after the empirical process. It was found that there was no statistically significant difference between the reading comprehension pre-test scores of the students in the experiment and control groups ( $>>05$ ). A t-test was conducted to determine whether the difference between the reading comprehension post-test scores of the students in the experiment and control groups was significant and the results are presented in Table 1.

Table 1

Independent samples t-test results on reading comprehension post-test scores of students in experiment and control groups

\begin{tabular}{llllllc}
\hline & $\mathrm{N}$ & $\overline{\mathrm{X}}$ & $\mathrm{SS}$ & $\mathrm{t}$ & $\mathrm{df}$ & Sig. (2-tailed) \\
\hline Experiment Group & 22 & 34,72 & 4,28 & 5,083 & 44 & 0,00 \\
Control Group & 24 & 27,25 & 5,54 & & & \\
\hline p
\end{tabular}

\section{$\mathrm{p}<.05$}

It was found that the " $t$ " value, which was calculated to determine the statistical significance of the difference between the mean student scores obtained in the post-test in experiment and control groups, was statistically significant at 0.05 significance level. Based on this finding, it can be argued that Turkish language instruction that was conducted with authentic task-based authentic material was effective on development of reading comprehension skills of the students in the present study.

The students in the experiment and control groups were asked to write an essay before and after the empirical process in the study. The essays were scored using the writing skills scale that was developed by Uysal (2009) by three field experts, one of whom was the author. The pre-test and post-test data were analyzed and interpreted with SPSS software. It was found that there was no statistically significant difference between the pre-test scores of the students in the experiment and control groups ( $p>.05)$. The $t$ test was applied to determine whether the difference between the writing skill post-test scores of the students in the experiment and control groups was significant and the results are presented in Table 2 .

Table 2

Independent samples t-test results on writing skills post-test scores of students in experiment and control groups

\begin{tabular}{lllllll}
\hline & $\mathrm{N}$ & $\overline{\mathrm{X}}$ & $\mathrm{SS}$ & $\mathrm{t}$ & $\mathrm{df}$ & Sig. (2-tailed) \\
\hline Experiment Group & 22 & 53,59 & 13,90 & 2,948 & 44 & 0.005 \\
Control Group & 24 & 39,05 & 18,90 & & & \\
\hline p $<.05$
\end{tabular}

$\mathrm{p}<.05$

It was found that the " $\mathrm{t}$ " value, which was calculated to determine the statistical significance of the difference between the mean post-test scores of the students in the experiment and control groups, was statistically significant at 0.05 significance level. Based on this finding, it can be argued that Turkish language instruction with authentic task-based authentic material affected the development of students' writing skills in the study. 
The writing motivation scale was applied to the students in the experiment and control groups before and after the empirical process. It was found that there was no statistically significant difference between the writing motivation scale pre-test scores of the students in experiment and control groups $(\mathrm{p}>.05)$. A t-test was conducted to determine whether the difference between the writing motivation post-test scores of the students in the experiment and control groups was significant and the results are presented in Table 3.

Table 3

Independent samples t-test results on writing motivation post-test scores of students in experiment and control groups

\begin{tabular}{lllllll}
\hline & $\mathrm{N}$ & $\overline{\mathrm{X}}$ & $\mathrm{SS}$ & $\mathrm{t}$ & $\mathrm{df}$ & Sig. (2-tailed) \\
\hline Experiment Group & 22 & 101,27 & 4,78 & 12,196 & 44 & 0.000 \\
Control Group & 24 & 77,54 & 8,11 & & &
\end{tabular}

$\mathrm{p}<.05$

It was found that the " $t$ " value, which was calculated to determine the statistical significance of the difference between the mean post-test scores of the students in the experiment and control group, was statistically significant at 0.05 significance level. Based on this finding, it can be argued that Turkish instruction with authentic task-based authentic materials was effective on students' writing motivations in the study.

\section{Findings Obtained with Qualitative Data}

The themes that emerged in the study were grouped under five main themes as follows: "My authentic Turkish language course", "My authentic materials", "My authentic tasks", "My literacy skills" and "How can it be better". Findings were summarized by including direct quotes of the participant statements.

\section{My authentic Turkish language course}

Analysis of the views of the students about the Turkish language course that was instructed with authentic task-based authentic materials demonstrated that the students described the Turkish course as 'very good', 'entertaining', 'instructive, informative, and beneficial' and 'similar to real life'. Dilek expressed her thoughts on the Turkish language course instructed with authentic task-based authentic material as follows: "The Turkish course was great in this semester. We read, we wrote. It was fun. Because the fact that what you brought to the class was similar to the things we use in daily life and these were informative was great and the things you brought to the class were always very useful in our normal life, so we were never bored, it was great."

\section{My authentic materials}

Analysis of the views of the students on authentic task-based authentic material, in other words, the course material, demonstrated that students considered these materials as 'similar to the articles used in daily life', 'educative-instructive', 'nice', 'entertaining', 'impressive', 'different', and 'goal-oriented'. Huseyin's thoughts on authentic, task-based authentic material were expressed as follows: "For example, we brought the objects we normally use in our daily lives to school and used those to read and write. I liked that 
very much. Because when I wanted to read a newspaper, I did it without knowing anything about the subject before, therefore I had no purpose, but when I brought the newspaper to school and read it after discussions on the subject, I read it with a purpose and I liked it a lot."

\section{My authentic tasks}

Findings on the student views on the activities conducted with authentic task-based authentic material were grouped under 4 sub-themes: 'Activities that the Students Liked,' 'Activities that the Students Disliked', 'Activities that the Students Found Difficult' and 'Activities that the Students Found Boring'. Analysis of the views of elementary school students on the instruction of Turkish language course with authentic task-based authentic materials demonstrated that the two most interesting activities for the students were creating books and reading and writing letters, and it was observed that the students liked the fact that their activities were observed by the others in the environment. Analysis of the negative views of the students on the activities conducted with authentic task-based authentic materials demonstrated that the majority of the students complained about the long texts. Most students stated that they experienced difficulties when creating books and reading-writing long manuscripts. Majority of the students were bored while reading and writing long manuscripts and spending time on the internet. Kübra expressed her views on the Turkish language course instructed with authentic task-based authentic material as follows: "I liked the letters and posters very much. Because I had a lot of fun doing it, so it was fun. I also liked the fact that what I wrote was read by others. I liked doing useful things for other people. We draw and hang posters for others to make sure that they eat healthy and designed books for younger students to introduce animals, so they benefited from it as well."

\section{My literacy skills}

Views of the students on the effect of Turkish language courses conducted with authentic task-based authentic materials were grouped under two categories: Views on reading skills and views on writing skills. Analysis of the views of the students on the effect of Turkish language course conducted with authentic task-based authentic materials on reading skills demonstrated that more than half of the students agreed that their reading comprehension skills had improved, half of the students stated that they now read faster and pay more attention to punctuation, almost one third stated that they are more willing to read, some students stated that they now love reading more than before, enjoy reading more, read more in their daily lives and their reading skills are permanent. On writing skills, half of the students stated that they now write more carefully, some students stated that they write better, and some others stated that they write with higher comprehension levels, they like to write, write faster and pat more attention to punctuation when writing. Ayşe expressed her views on the developments in her reading skills as follows: "My reading improved, I now understand what I read, before, I didn't, I just read and moved on, now I comprehend it better. What I read is similar to what I do in my daily life, so I enjoy these better. Now I read willingly. I now wonder about what we will read. I always want to read more." Erdal said the following about the improvements in his writing skills: "My writing improved a lot. My script 
became even better. I also know that we do not write for the sake of it, now I am willing to write. I love it so much. Of course, I did not write as randomly as I wrote before, I paid a little more attention since other people would see what I wrote."

\section{How can it be better?}

The recommendations of the students about the Turkish language course instructed with authentic task-based authentic material were grouped under the following 4 sub-themes: 'Properties of the course material', 'Practical activities that can be conducted in the course', 'General Recommendations' and 'Others'. Analysis of the recommendations of the students on the instruction of Turkish language course with authentic task-based authentic materials demonstrated that students mostly recommended the use of shorter texts and the availability of the chat function in the internet blog designed for the course. About in-class practices, students suggested to author more books and the distribution of the posters and brochures they created throughout the city and the students wanted to write letters more often and to a larger number of individuals. Furthermore, they requested to promote the internet blog they created and inclusion of their videos in the blog. Ayşe recommended the following on the instruction of the Turkish language course with authentic task-based authentic material: "I would like to hang the posters we created on the streets. I would like to distribute the brochures to everyone on the streets, let everybody see our class journal. Then, for example, we organized nature, environment, arts or other clubs, and I would like to organize a rally for the preservation of the nature. I mean, I would like more people to see the things we did."

\section{DISCUSSION}

The objective of the present study was to determine the effect of authentic task-based authentic material on reading comprehension, writing motivation and writing skills in Turkish language course. One of the results of the present study that was conducted to determine the impact of authentic task-based authentic material use in Turkish language course demonstrated that authentic task based authentic material were effective in the development of reading comprehension and writing skills. This finding provides a significant contribution to the literature. Because, according to Uluğ (2000, p.32), reading skills are the most important means of achieving success at school and the most important tool to acquire knowledge at the same time. Furthermore, reading skills are also quite effective in increasing the overall success of the educational process, improving the vocabulary, and developing the ability of learners to comprehend the grammatical structure of the language (Stadler, 1980, p. 328). Writing skills are the most difficult and complex skills to acquire, and therefore, it is necessary to assign a distinct time and attention for the training of these skills. These skills also determine the quality and improvement of listening, speaking and reading skills (Dara, 2000, p. 23).

The effect of authentic task-based authentic material on the development of basic language skills in native language instruction was investigated and parallel results were obtained (Biggs et al., 2008; Karadağ \& Kayabaş1, 2011; Ünlüer \& Yaşar, 2012). In a study conducted by Doğan (2007), a listening training program that included authentic tasks and materials was developed to improve the listening skills of junior high school 
students. Material such as stories, subway announcements, weather and news reports, drawings, interviews, address descriptions, radio theater, commercials, dictation and shopping problems that are were frequently used by the students in their lives were used to improve their listening skills in the study. Study results demonstrated that the training program that was designed with these materials was effective on the development of students' listening skills. Consistent with this finding, Dogan (2007) stated that authentic material taken from daily life can be used effectively in the development of basic language skills of the students in mother tongue courses. In a study conducted by Gambrell et al. (2011), the effect of correspondence with letter, an authentic task, on literacy skills of the students was investigated. In the study, students established a pen pal and corresponded with this individual for a period of time.

The results obtained from the study suggested that such authentic tasks significantly supported the development of students' literacy skills. Berardo (2006) also noted that the use of authentic material was quite useful in improving reading skills and motivates students for future reading. Purcell-Gates and Duke (2004) organized authentic reading and writing activities in a science course and demonstrated that students achieved a higher progress in reading, comprehension and writing skills (Cited by Duke et al., 2006). Siegel (2006, p. 68) stated that due to the requirements of our age, all literacy forms should be included in the development of language skills. The material that would be selected for the development of language skills in Turkish language courses should include material that the students encounter in their daily lives outside the school (Tüzel, 2013, p.135). Authentic tasks and materials allow students to learn a language better and become fluent in this language faster. Furthermore, authentic tasks and material make the students feel more confident since they are part of their daily life activities (Harmer, 1994, p. 57). It can be observed that implementation and studies on the use of authentic tasks and materials in language instruction mostly focused on the field of the instruction of a foreign language (Gilmore, 2011; Masood, 2013; Sabet \& Mahfesat, 2012).

The results of these studies suggest that authentic tasks and materials have a positive effect on the development of language skills in the process of foreign language instruction. For instance, Masood (2013) investigated the effectiveness of authentic material in developing English writing skills of the students and found that authentic material improved students' writing skills, curiosity, motivation, and that daily life material were introduced to the classroom environment thanks to these materials and monotony caused by artificial texts in the textbooks was removed. According to previous studies, carefully selected and utilized authentic materials are extremely valuable for literacy classes. These materials increase the writing potential of the students and improve their listening comprehension skills (Sabet \& Mahsefat, 2012). In a study conducted by Gilmore (2011) in a classroom for 10 months with 62 students, it was concluded that authentic materials and related authentic tasks were effective in the development of communication skills of the students. In the present study, it was concluded that authentic task-based authentic materials are effective in the development of reading and writing skills in the native language. Literature review would demonstrate that the findings of the present study are consistent with the results of similar studies on the development of language skills with authentic material. 
In the present study, it was further found that authentic task based authentic material improved writing motivation. Since authentic tasks and material provided the language use at school and in the natural context, they improved students' motivations and learning levels (Erdem, 2006). Furthermore, authentic task based authentic material exposed the students to the natural use of the language, which meant that the language used at school and in the classroom was more relevant to the needs of students. These tasks and material, thus, increase the motivation of the students (Al Azri \& Al-Rashdi, 2014 , p. 252). This finding of the present study was consistent with the results of the study by Guariento and Morley (2001), who stated that especially when authentic material were not chosen with care by the teachers, use of this material would surprise the low-level students and decreased their motivation. However, in the present study, authentic materials were selected with care and according to the level of the students. Hanson-Smith (2001) stated that computers are considered as an authentic material in the computer-based education and this authentic material increases motivation as well. Peacock (1997, p.156) emphasizes that motivation significantly increases with the use of authentic material.

Based the qualitative findings of the present study, it was concluded that the participants' general views on the Turkish language course were positive and the authentic task based authentic material used in the Turkish course were considered to be fun, useful and similar to real life experiences. It was considered that the fact that Turkish language students experienced real-life activities in the classroom removed the prejudices of the students against the course, especially the fact that the course was not instructed strictly using the textbook and performance of the activities that were similar to their daily lives could be the reason why they perceived this method as entertaining. The above finding of the present study was also consistent with the results of certain studies in the literature. The qualitative data collected by Sabet and Mahsefat (2012) demonstrated that students exhibited positive attitudes and satisfaction towards authentic material. In the present study, it was determined that visibility of the student activities, creating books, reading/writing letters, reading and writing recipes and playing games were the activities that the students enjoyed the most, while most of the students stated that there was no activity that they disliked. Students did not like the fact that the reading texts were long, the activities were visible by everyone, and the short and inattentive letters they received from their pen pals. Most students expressed that they experienced reading difficulties due to the length of the texts and they were bored reading these texts. Furthermore, students also complained that they experienced problems during the activities of authoring books and designing posters. In addition, certain students also stated that they were bored of being on the internet all the time. This study finding is partially consistent with the results of the studies in the literature. In a study conducted by Ünlüer and Yaşar (2012), the students stated that they did not experience any difficulty in using authentic material in the class. Participants stated that their reading comprehension was improved, they were able to read faster and paid better attention to punctuation marks, they were more willing to read, they loved reading more than before, and they also stated that they wrote better, more attentively, understood their writing better and were more willing to write as a result of the use of the activities conducted 
with authentic task-based authentic material. Classroom teacher, on the other hand, stated that the use of reading texts that are used in daily life increased the interest of the students in reading, their reading comprehension, and reading speed and their writing skills improved and students began to write better, attentively and more willingly. In a study conducted by Karadağ and Kayabaşı (2011) with authentic material, interviews were conducted with the students after the study, and it was observed that authentic material primarily contributed to the development of the writing skills including other language skills, as well as their personal development. In the interviews conducted with the students in the present study, students recommended that the posters and brochures they created should be distributed throughout the city and they desired to write letters more often and to a greater number of individuals, to author a greater number of books, to promote their blog and stated that they preferred to tackle with shorter texts about the Turkish language instruction conducted with authentic task-based authentic material. One of the most important reasons why authentic task-based authentic materials are advantageous is that the activities conducted by the students are visible by others, motivating the students. That was why the students desired to get more people involved in the activities they conducted. Students also recommended that the selected texts should be shorter. Parallel to the said recommendation, studies in the literature concluded that short and simple sentences are easier to read when compared to long and complex sentences, thus, they are easier to learn and to perceive (Acarlar, Ege \& Turan, 2002). Furthermore, the abovementioned study indicated that reasons such as the fact that reading on the frequently used screen complicates natural eye movements, continuous interruption of the reading on a screen, reflection of the ambient light from the screen, continuous glowing, combination of the partial information by the mind tire both the mind and the eye (Güneş, 2010). Güneş (2010) also stated that the length of the texts to be read on screen should be short.

Based on study findings, the following recommendations can be made: Authentic taskbased authentic material should be used in Turkish language courses to enable learners to use and improve their literacy skills. In-service training programs should be organized for teachers to use authentic task-based authentic materials in Turkish language courses. Thus, teacher contact meetings should be organized and cooperation with the education faculties in the universities should be maintained. The parents should be informed about authentic task-based authentic material and their awareness on the matter should be raised. Further research that would utilize different data sources can be conducted to determine the effect of authentic task-based authentic material on literacy skills. Studies that demonstrate the effect of authentic task-based authentic material on different grade levels and different language skills can be conducted. 


\section{CONCLUSION}

A general assessment of study findings demonstrated that use of authentic task-based authentic material in Turkish language course improved reading comprehension and writing skills and writing motivation of 4th grade primary school students. Furthermore, it was identified that participating students had positive views on the Turkish language course instructed using authentic task-based authentic material. It was observed that the students found the authentic material similar to the material they encounter in their daily lives, and stated that they liked the activities of book creation and letter reading-writing. It was found that the students experienced problems and got bored with book writing and reading and writing long texts. Another finding obtained in the study was that students tend to comprehend better what they read or wrote, their reading was permanent, they read and wrote faster, loved reading and writing better after the instruction and were more motivated to engage in these activities, were more careful with the punctuation and more meticulous in reading and writing activities thanks to the use of authentic material.

\section{REFERENCES}

Acarlar, F., Ege, P., \& Turan, F. (2002). Türk çocuklarında üstdil becerilerinin gelişimi ve okuma ile ilişskisi. Türk Psikoloji Dergisi, 17 (50), 63-73.

Al Azri, R. H., \& Al-Rashdi, M. H. (2014). The effect of using authentic materials in teaching. International Journal of Scientific and Technology Research, 3 (10), 249-254.

Alkan, Z. N. (2007). Illköğretim beşinci sinıf öğrencilerinin yazılı anlatım hataları (Master thesis). Osmangazi Üniversitesi, Eskişehir.

Bacon, S. M., \& Finneman M. (1990). A study of the attitudes, motives and strategies of university foreign-language students and their disposition to authentic oral and written input. Modern Language Journal, 74, 459-73

Bektaş, M. ,\& Horzum, M. B. (2012). Otantik öğrenme (2.bs.). Ankara: Pegem.

Berardo, S.A. (2006). The use of authentic materials in the teaching of reading. The Reading Matrix, 6 (2), 60-69.

Biggs, M. C., Homan, S. P., Dedrick, R., Minick, V., \& Rasinski, T. (2008). Using an interactive singing software program: A comparative study of struggling middle school readers. Reading Psychology, 29 (3), 195-213.

Bulut, B. (2013). Etkin dinleme eğitiminin dinlediğini anlama, okuduğunu anlama ve kelime hazinesi üzerine etkisi (Master thesis). Adnan Menderes Üniversitesi, Aydın.

Büyüköztürk, Ş. (2010). Veri analizi el kitabı. Ankara: Pegem.

Caseley, P. M. (2004). Towards an authentic pedagogy: An investigation of authentic learning instruction in a middle school. (Master thesis). Available from ProQuest Dissertations and Theses database. (UMI No. 1423284). 
Cholewinski, M. (2009). An Introduction to constructivism and authentic activity. Journal of the School of Contemporary International Studies Nagoya University of Foreign Studies, 5, 283-316.

Creswell, J. W. (2013). Araştırma deseni: Nitel, nicel ve karma yöntem yaklaşımları. (S. B. Demir, Çev.). Ankara: Eğiten Kitap.

Creswell, J. W., \& Plano Clark, V. L. (2014). Karma yöntem araştırmaları, tasarımı ve yürütülmesi (2. Baskıdan çeviri). (Y. Dede ve S. B. Demir, Çev.). Ankara: Anı.

Dara, R. (2000). Yazılı anlatıma giriş. İstanbul: Asa Kitabevi.

Demirel, Ö., \& Şahinel, M. (2006). Türkçe ve sinlf öğretmenleri için Türkçe öğretimi (7.bs.). Ankara: Pegem.

Doğan, Y. (2007). İlköğretim ikinci kademede dil becerisi olarak dinlemeyi geliştirme çalışmaları (Doctoral thesis). Gazi Üniversitesi, Ankara.

Doğan, Y. (2014). Yabancılara Türkçe kelime öğretiminde market broşürlerinden yararlanma. Journal of Language and Linguistic Studies, 10 (1), 89-98.

Duke, N.K., Purcell- Gates V., Hall, L.A. \& Tower, C. (2006). Authentic literacy activities for developing comprehension and writing. The Reading Teacher, 60 (4), 344355.

Erdem, M. (2006). The use of authentic reading materials to promote motivation (Master thesis). Gazi Üniversitesi, Ankara.

Gambrell, LB., Hughes, E.M., Calvert, L., Malloy, T.A., \& Igo, B. (2011). Authentic reading, writting and discussion. Elementary School Journal, 112 (2), 234-258.

Gilmore, A. (2011). "I prefer not text": Developing Japanese learners' communicative competence with authentic materials. Language Learning, 61 (3), 786-819.

Guariento, W., \& Morley, J. (2001). Text and task authenticity in the EFL classroom. ELT Journal, 55 (4), 347-353.

Güneş, F. (2010). Öğrencilerde ekran okuma ve ekranik düşünme. Mustafa Kemal Üniversitesi Sosyal Bilimler Enstitüsü Dergisi, 7 (14), 1-20.

Hanson-Smith, E. (2001). Computer assisted language learning. In Carter R \& Nunan D (Eds.). The Cambridge guide to teaching English to speakers of other languages (p.109-110). Cambridge: Cambridge University Press.

Harmer, J. (1994). The Practice of English language teaching. London: Longman.

Herrington, J., Reeves, T.C. \& Oliver, R. (2006). Authentic tasks online: A synergy among learner, task and technology. Distance Education, 27 (2), 233-247.

Jacobson, E., Degener, S., \& Purcell- Gates V. (2003). Creating authentic materials and activities for the adult literacy classroom: A handbook for practitioners. Retrieved 01 July, 2014 from http://www.ncsall.net/fileadmin/resources/teach/jacobson.pdf 
Karadağ, R., \& Kayabaşı, B. (2011). Yazılı anlatım becerilerinin geliştirilmesinde okuma metinleri olarak gazete köşe yazılarının kullanılması. Turkish Studies, 6 (3), 9891010 .

Kendall, M.G., \& Babington, S. (1939). The problem of m rankings. The Annals of Mathematical Statistics, 10 (3), 275-287.

Lee, Y. W. (1995). Authenticity revisited: Text authenticity and learner authenticity. ELT Journal, 49 (4), 323-328.

Lincoln, Y. S., \& Guba, E.G. (1985). Naturalistic inquiry. Beverly Hills, California: Sage Publications.

Masood, A. (2013). Exploiting authentic materials for developing writing skills at secondary level-an experimental study. Journal for the Study of English Linguistics, 1(1), 21-71.

Oura, G. K. (2001). Authentic task-based materials: Bringing the real world into the classroom. Sophia Junior College Faculty Bulletin, 21, 65-84.

Öztürk, E. (2013). Assessment of writing motivations and activities of the 4th grade primary school students. International Journal of Academic Research, 5 (4), 293-299.

Peacock, M. (1997). The effect of authentic materials on the motivation of EFL learners. ELT Journal, 51 (2), 144-156.

Sabet, M. K., \& Mahsefat, H. (2012). The impact of authentic listening materials on elementary EFL learners' listening skills. International Journal of Applied Linguistics \& English Literature, 1 (4), 216-229.

Siegel, M. (2006). Rereading the signs: Multimodal transformations in the field of literacy education. Language Arts, 84 (1), 65-77.

Stadler, A. (1980). Children of guest workers in Europe: Social and culturel needs in relation to library services. Library Trends, 29 (2), 325-334.

Tabachnick, B. G., \& Fidell, L. S. (2000). Using multivariate statistics (4th ed.). New York: Allyn and Bacon.

Tüzel, S. (2013). Çok katmanlı okuryazarlık öğretimine ilişkin Türkçe öğretmen adaylarının görüşlerinin incelenmesi. Eğitimde Kuram ve Uygulama, 9 (2), 133-151.

Uluğ, F. (2000). Okulda başarı (7. Bask1). İstanbul: Remzi Kitabevi.

Uysal, M. E. (2009). Illköğretim Türkçe dersinde işbirlikli öğrenmenin erişi, eleştirel düşünce ve yaratıcllı becerilerine etkisi (Doctoral thesis). Dokuz Eylül Üniversitesi, İzmir.

Ünlüer, G., \& Yaşar, Ş. (2012). Sosyal bilgiler dersinde gazete kullanımına ilişkin öğrenci görüşleri. Eskişehir Osmangazi Üniversitesi Sosyal Bilimler Dergisi, 13 (1), 43 57. 
Volman, M. J., Van Schendel, B. M., \& Jongsman, M. J. (2006). Handwriting difficulties in primary school children: A search for underlying mechanisms. The American Journal of Occupational Therapy, 60 (4), 451-460.

Yıldırım, A., \& Şimşek, H. (2011). Sosyal bilimlerde nitel araştırma yöntemleri (8.baskı). Ankara: Seçkin Yayıncılık. 